\title{
KEMENARIKAN KONTEN BERITA DALAM MENARIK MINAT PEMBACA MAJALAH BUMI MINA TANI
}

\section{THE ATTRACTIVENESS OF NEWS CONTENT IN ATTRACTING READERS' INTEREST OF BUMI MINA TANI MAGAZINE}

\author{
Putri Oktiningtyas \\ Sekretariat Daerah Kabupaten Pati \\ Email: putri.oktyas@gmail.com
}

Naskah Masuk: 25 Juli 2018

Naskah Revisi: 1 Oktober 2018

Naskah Diterima: 19 Oktober 2018

\begin{abstract}
Bumi Mina Tari (BMT) magazine is distributed regularly to all government institutions in Pati District, includes Regional Secretary Office (Setda). It aims to improve employe's knowledge regarding programs/actions and regulations that are conducted by the local government. The objectives of this study are: (1) to describe the attractiveness of news content of BMT Magazine and readers' interest to read the magazine and (2) to analyse the correlation between the two variables. The study used quantitative approaches, especially descriptive and correlational. The number of samples was 25 employees of Setda were chosen randomly. The data were analysed using descriptive and Spearman rank tests. The study resulted: (1) The use of language and The easiness to understand news content were the largest contributors to the attractiveness of News Content Variable; (2) Meanwhile, Reading Motivation and Satisfaction of news materials were the largest contributors to Readers' Interest Variable. (3) There was a positive and significant correlation between the attractiveness of news contents and readers' interest of the employees Setda, Pati District
\end{abstract}

Keywords: news content, bumi mina tani magazine, readers' interest

\begin{abstract}
ABSTRAK
Pendistribusian majalah Bumi Mina Tani (BMT) di seluruh Perangkat Daerah, termasuk Sekretariat Daerah (Setda) diharapkan dapat meningkatkan pengetahuan ASN terhadap program kegiatan serta kebijakan yang dibuat oleh Pemerintah Daerah. Penelitian ini bertujuan untuk (1) Menggambarkan kemenarikan Majalah BMT dan minat membaca karyawan Setda Kabupaten Pati dan (2) Menganalisis korelasi antara kedua variabel tersebut. Penelitian menggunakan pendekatan kuantitatif, baik deskriptif maupun korelasional. Sampel penelitian adalah 25 karyawan Setda Kabupaten Pati yang dipilih secara acak. Data yang didapat diolah menggunakan uji deskriptif dan Spearman Rank. Hasil penelitian menunjukkan bahwa (1) Dimensi Penggunaan Bahasa dan Kemudahan Memahami Isi Berita memberikan kontribusi terbesar terhadap variabel Kemenarikan Isi Majalah BMT; (2) Motivasi Membaca dan Kepuasan terhadap Bacaan memberikan kontribusi tertinggi terhadap variabel Minat Membaca; (3) Terdapat hubungan positif dan signifikan antara kemenarikan isi majalah dengan minat membaca karyawan Setda.
\end{abstract}

Kata kunci : isi berita, majalah bumi mina tani, minat membaca

\section{PENDAHULUAN}

Pemerintah daerah (pemda) membutuhkan media komunikasi tertentu untuk menyampaikan informasi berkaitan dengan penyelenggaraan pemerintahan. Salah satu media komunikasi yang banyak digunakan oleh pemerintah daerah adalah majalah. Hal tersebut telah dilakukan oleh Pemerintah Kabupaten (Pemkab) Pati dengan menerbitkan secara berkala Majalah Bumi Mina Tani (BMT).

Penerbitan Majalah BMT dilakukan oleh Bagian Humas Sekretariat Daerah (Setda). Majalah BMT diterbitkan sejak tahun 1988. Sebagai media resmi pemerintah, Majalah 
BMT memberikan informasi, utamanya tentang kegiatan bupati sebagai kepala daerah dan kebijakan-kebijakan yang dibuat oleh pemerintah daerah. Jumlah eksemplar di tiap edisinya adalah 2500 buah yang diedarkan di seluruh perangkat daerah dan desa di seluruh wilayah Kabupaten Pati.

Selama 15 tahun penerbitannya, Majalah BMT telah mengalami beberapa kali pergantian layout hingga konten berita. Adapun rubrik yang sekarang ini ditampilkan di Majalah BMT adalah Derap Pemkab, Laporan Utama, Forum Muspida, Edukasiana, Pelayanan Publik, Noto Praja, Medika, Ekonomi Bisnis, Caping Tani Nelayanan, Humaniora, Rekam Lensa, Ragam, Jelajah Kadipaten, Pembangunan, Ragam, Ngudho Roso, dan Jendela Hati.

Terdapat beberapa kendala yang dihadapi dalam pengelolaan Majalah BMT. Kendala pertama berkaitan dengan ketepatan waktu pendistribusian majalah. Terkadang, penyaluran Majalah BMT melebihi target waktu sehingga informasi yang disajikan terkesan sudah kadaluwarsa. Sebagai akibatnya adalah kondisi ini dapat menyebabkan keengganan pembaca membaca Majalah BMT. Kendala kedua berkaitan dengan pengelolaan Majalah BMT. Pengelolaan majalah yang berbobot diharapkan dapat meningkatkan eksistensi dan membentuk citra positif pemerintah daerah di tengah masyarakat (Astrid, 2017).

Pengelolaan majalah tidak hanya sebatas pada organisasi kepengurusan majalah, namun juga konten majalah. Majalah yang memiliki konten yang berkualitas diharapkan mampu menarik perhatian khalayak untuk membaca. Parameter konten yang berkualitas dapat dilihat dari penyusunan tata letak (layout), penggunaan bahasa, serta isi pemberitaan.

Tata letak (layout) merupakan salah satu pembeda majalah dengan media komunikasi lainnya. Ardianto \& Komala (2004) menyatakan bahwa layout merupakan daya tarik pertama dari sebuah majalah. Majalah pada umumnya memiliki jumlah halaman yang lebih banyak (tebal), sehingga penggunaan banyak gambar dan dicetak di kertas yang berkualitas diharapkan dapat menarik minat pembaca.

Selain tata letak, kualitas majalah bisa dilihat dari penggunaan bahasa. Sebagaimana media komunikasi massa lainnya, bahasa yang digunakan oleh majalah diharapkan dapat mengikuti bahasa jurnalistik. Bahasa jurnalistik merupakan bahasa yang digunakan oleh para wartawan, redaktur atau pengelola media massa dalam menyusun, menyajikan, memuat, menyiarkan, dan menayangkan berita serta laporan peristiwa atau pernyataan yang benar, aktual, penting dan atau menarik dengan tujuan agar mudah dipahami isinya dan cepat ditangkap maknanya (Sumadiria, 2006).

Kriteria konten majalah yang berkualitas juga berkaitan dengan isi pemberitaan. Sebagai media komunikasi pemerintah daerah, Majalah BMT menampilkan laporan utama berupa kebijakan serta program/kegiatan yang dilakukan oleh Pemerintan Daerah Kabupaten Pati. Selain itu, melalui Rubrik Derap Pemkab, Majalah BMT juga memberikan informasi mengenai kegiatan Bupati dan Wakil Bupati dalam satu bulan.

Salah satu sasaran penyebaran Majalah BMT adalah Sekretariat Daerah (Setda) Kabupaten Pati. Karyawan Setda dituntut untuk mengetahui kebijakan-kebijakan pimpinan tertinggi di tingkat Kabupaten, yaitu Bupati. Penyebaran informasi tentang kebijakan tidak hanya melalui surat resmi antar bagian saja tetapi juga melalui pemberitaan di Majalah BMT. Upaya tersebut dilakukan agar para karyawan Setda memiliki pengetahuan tentang kebijakan yang dibuat pimpinan. 
Berdasarkan latar belakang tersebut, tujuan penelitian ini adalah (1) Menggambarkan kemenarikan Majalah BMT serta minat membaca pada karyawan Setda Kabupaten Pati; (2) Menganalisis hubungan antara kemenarikan konten berita di dalam Majalah Bumi Mina Tani dengan minat membaca karyawan Setda Kabupaten Pati, dengan hipotesis yang diajukan adalah "Terdapat hubungan positif antara kemenarikan Majalah Bumi Mina Tani dengan minat membaca karyawan Setda Kabupaten Pati."

\section{TINJAUAN PUSTAKA}

\section{Karakteristik Majalah}

Sejak awal, terbitnya tipe suatu majalah ditentukan oleh sasaran khalayak yang dituju. Artinya, redaksi sudah menentukan siapa yang akan menjadi pembacanya dari kategori usia. Bisa juga majalah itu mempunyai sasaran pembaca dengan profesi tertentu atau pembaca yang memiliki hobi tertentu (Ardianto \& Komala, 2004).

Majalah memiliki beberapa kelebihan yaitu: (1) Media tercetak adalah satu-satunya media dimana khalayak dapat mengatur tempo dalam membaca, sehingga pembaca dapat mengulang membacanya; (2) Karena sifatnya yang tercetak, pesan-pesannya bersifat permanen dan kekuatan utamanya adalah dapat dijadikan sebagai bukti (Assegaf, 2004).

Ardianto \& Komala (2004) menjabarkan karakteristik majalah sebagai berikut:

1. Penyajian lebih mendalam, karena frekuensi terbit pada umumnya mingguan hingga bulanan sehingga memungkinkan reporter untuk menggali informasi dari suatu peristiwa dan menjadikan berita dalam majalah disajikan lebih lengkap.

2. Nilai aktualitas lebih lama, karena pembaca tidak pernah bisa membaca majalah tuntas sekaligus.
3. Gambar/foto lebih banyak, karena jumlah halaman majalah lebih banyak, sehingga selain penyajian berita yang mendalam, majalah juga dapat menampilkan gambar/ foto yang lengkap dengan kualitas kertas yang digunakan pun lebih baik.

4. Cover (sampul) sebagai daya tarik, juga menjadi ciri khas suatu majalah, sehingga sepintas pembaca dapat mengidentifikasikan majalah tersebut.

Penjabaran karakter majalah diterapkan dalam setiap penyusunan majalah agar pembaca bisa mendapatkan manfaat dari membaca majalah juga sebagai ciri khas majalah dibandingkan dengan media cetak lainnya.

Bila dilihat dari karakteristiknya, majalah memungkinkan pembaca untuk memperoleh suatu nilai lebih saat membaca majalah. Terdapat dua jenis pembaca. Pembaca jenis pertama adalah membaca media untuk mendapatkan pengetahuan sehingga dapat mengatasi masalah yang timbul. Adapun pembaca jenis kedua adalah mencari informasi dengan tujuan meninjau keadaan sekeliling dan ia akan segera menyesuaikan diri dengan keadaan sekelilingnya (Meinanda, 1981).

Konten dari sebuah majalah merupakan berita. Berita dapat dipahami sebagai laporan tentang fakta atau ide yang termassa, yang dapat menarik perhatian pembaca, karena sesuatu yang luar biasa, penting, mencakup sisi human interest seperti humor, emosi dan ketegangan (Assegaf dikutip Sumadiria, 2005). Sebuah berita diharapkan memenuhi enam unsur "Siapa, Apa, Mengapa, Dimana, Bilamana, dan Bagimana". Oleh karena itu, sebuah berita harus berisi suatu ide yang memiliki daya tarik, aktual, akurat, dianggap penting bagi sebagian besar penduduk, serta diedarkan secara cepat melalui media berkala.

Penulisan berita yang ada di majalah harus sesuai dengan kaidah/ketentuan jurnalistik dengan menggunakan bahasa 
jurnalistik. Bahasa yang digunakan dalam penulisan berita haruslah memenuhi beberapa unsur sehingga mudah dipahami dan mampu menarik minat pembaca (Sumadiria, 2006). Namun demikian, sebuah berita tidak boleh membohongi pembaca dengan menuliskan judul yang memukau namun dengan isi berita yang biasa-biasa saja. Selain itu, rangkaian kata yang digunakan dalam menuliskan berita harus memenuhi unsur tegas, jelas, dan menarik sehingga tidak membingungkan pembaca serta mampu membangkitkan minat dan perhatian untuk membaca (Sumadiria, 2006).

\section{Minat Baca}

Definisi minat dalam Kamus Bahasa Indonesia adalah kecenderungan atau keinginan hati terhadap objek tertentu. Minat seseorang timbul pertama-tama dimulai dari adanya objek tertentu yang diperhatikan, kemudian dari objek yang diperhatikan itu timbul suatu rangsangan untuk tertarik dan diakhiri dengan kepentingan yang ada (Poerwodarminto, 1985) Minat juga dapat diartikan sebagai perhatian yang tekun, kuat, dan lebih menguasai individu secara mendalam. Biasanya seseorang memperhatikan karena ia tertarik, berkepentingan, memerlukan atau senang pada sesuatu (Meichati, 1972)

Minat baca menurut Rahim (2005) adalah keinginan yang kuat disertai usahausaha seseorang untuk membaca. Orang yang mempunyai minat membaca yang kuat akan diwujudkannya dalam kesediaannya untuk mendapat bahan bacaan dan kemudian membacanya atas kesadarannya sendiri. Dapat disimpulkan bahwa minat membaca ialah perhatian yang kuat disertai usaha-usaha seseorang untuk membaca, dengan kesadarannya sendiri untuk mendapatkan suatu bahan bacaan dan kemudian membacanya.

Terdapat dua aspek berkaitan dengan minat baca, yaitu aspek kognitif dan afektif.
Aspek afektif mempunyai peran yang lebih penting dari aspek kognitif. Hal ini disebabkan: (1) aspek afektif lebih besar peranannya dalam memotivasi tindakan daripada aspek kognitif; (2) aspek afektif yang sudah terbentuk cenderung lebih tahan terhadap perubahan dibandingkan aspek kognitif.

\section{METODE PENELITIAN}

Pendekatan yang digunakan dalam penelitian ini adalah kuantitatif. Secara lebih spesifik, penelitian ini merupakan penelitian eksplanatori yaitu menjelaskan hubungan kausal antara variabel-variabel yang diteliti melalui pengujian hipotesis (Singarimbun, 1989). Korelasi yang dianalisis adalah hubungan kemenarikan isi berita sebagai variabel bebas (X) dengan minat pembaca Majalah BMT sebagai variabel terikat (Y).

Lokasi penelitian adalah Sekretariat Daerah (Setda) Kabupaten Pati. Populasi penelitian adalah karyawan yang bekerja di Setda Kabupaten Pati berjumlah 222 orang. Teknik penarikan sampel yang digunakan adalah proporsional random sampling. Jumlah sampel yang terlibat didasarkan pada asumsi bahwa sebenarnya tidak ada ketentuan yang mutlak tentang berapa persen suatu sampel harus diambil dari populasi yang ada. Ketidaktetapan mutlak tersebut tidak perlu menimbulkan keraguan pada seorang peneliti (Hadi, 1986). Oleh karena itu, peneliti menetapkan jumlah sampel sebesar $10 \%$ dari populasi di setiap bagian yang ada di Setda Kabupaten Pati dengan rincian Bagian Tata Pemerintahan, Humas, Hukum, Perekonomian, Kesejahteraan Rakyat (Kesra), Pembangunan, dan Organisasi. Masing-masing bagian diwakili oleh dua (2) orang responden. Adapun Bagian Umum dan Bagian Perlengkapan diwakili masing-masing empat (4) dan tujuh (7) orang responden. Oleh karena itu, jumlah 
total sampel secara keseluruhan adalah 25 responden.

Terdapat dua jenis data yang digunakan dalam penelitian ini, yaitu data primer dan data sekunder. Data primer diperoleh langsung dari responden di lapangan melalui wawancara dan pengisian kuesioner. Data sekunder merupakan data yang didapat melalui studi pustaka \& dokumen yang relevan dengan tema penelitian.

Teknik pengolahan data utamanya menggunakan metode kuantitatif. Analisis kuantitatif deskriptif digunakan untuk menggambarkan persebaran sampel penelitian di setiap variabel penelitian. Adapun analisis kuantitatif korelasional digunakan untuk menghitung korelasi antara variabel bebas dengan variabel terikat. Pengujian korelasi kedua variabel penelitian menggunakan uji Spearman rank.

\section{HASIL DAN PEMBAHASAN}

\section{Kemenarikan Isi Majalah}

Variabel kemenarikan isi majalah diukur melalui empat dimensi, yaitu layout majalah, judul berita, penggunaan bahasa, dan kemudahan mengerti isi berita. Berdasarkan keempat dimensi tersebut, penggunaan bahasa dan kemudahan mengerti isi berita memberikan kontribusi tertinggi terhadap kemenarikan isi majalah.

Kesesuaian penggunaan bahasa diukur menggunakan tiga item pertanyaan, yaitu: (1) Apakah bahasa yang digunakan dalam setiap berita dapat menarik perhatian pembaca untuk melanjutkan membaca; (2) Apakah pembaca dapat memahami penggunaan bahasa yang ada dalam setiap berita dalam Majalah BMT; serta (3) Apakah bahasa yang digunakan dalam Majalah BMT sudah sesuai dengan harapan pembaca.

Analisis deskriptif menunjukkan bahwa sebagian besar responden penelitian (72\%) mempersepsikan bahwa bahasa yang digu- nakan oleh Majalah BMT sudah sangat sesuai dan mudah dipahami dan $16 \%$ lainnya menyatakan bahasa yang digunakan cukup sesuai. Hal tersebut mengindikasikan bahwa Majalah BMT telah menggunakan bahasa secara efektif sehingga pesan dalam berita juga dapat disampaikan secara efektif.

Bahasa merupakan aspek yang penting dalam aktivitas jurnalistik. Ragam bahasa jurnalistik berbeda dengan ragam bahasa lainnya, seperti bahasa ilmu, bahasa sastra, dan bahasa baku. Bahasa jurnalistik dicirikan sebagai baasa yang informatif, persuasif, bisa dipahami secara umum, singkat, dan jelas. Lebih lanjut, dalam perkembangannya, bahasa jurnalistik tidak hanya berperan dalam penyampaian informasi, melainkan juga berfungsi menarik pembaca sebanyak-banyaknya. Oleh karena penyusun berita juga mulai menggunakan bahasa jurnalistik yang sensasional (Poentarie, 2015)

Dimensi kemudahan mengerti isi berita diukur menggunakan tiga item pertanyaan yaitu: (1) Bagaimana isi berita yang ditulis dalam Majalah BMT selama ini?; (2) Apakah isi berita/ informasi yang ditulis dalam Majalah BMT selama ini menarik?; serta (3) Apakah pembaca dapat memahami isi berita yang ada pada Majalah BMT? Analisis deskriptif terhadap Dimensi Kemudahan Mengerti Isi Berita menunjukkan bahwa sebagian besar responden penelitian (72\%) menganggap isi berita yang dimuat di Majalah BMT sangat mudah dipahami dan $12 \%$ lainnya menganggap isi berita mudah dipahami.

Penulisan isi berita yang baik, dengan isi berita atau informasi yang disampaikan dengan menarik membuat responden dapat mengerti isi tulisan yang ada di majalah. Penulisan berita dan kemenarikan informasi yang ditampilkan menjadikan para responden penelitan dapat memahami isi berita dalam Majalah BMT dengan baik. 
Terkait indikator kemenarikan layout majalah, responden diberi pertanyaan sebagai berikut : (1) bagaimana layout atau tampilan Majalah BMT saat ini; (2) apakah tampilan depan/cover Majalah BMT menjadi daya tarik utama untuk membaca Majalah BMT; serta (3) apakah ilustrasi/gambar pada setiap berita, sudah sesuai dengan isi berita. Analisis deskriptif menunjukkan bahwa sebagian besar sampel (44\%) menganggap layout Majalah BMT menarik dan diikuti 28\% lainnya menganggap layout majalah sangat menarik.

Hasil penelitian ini mengindikasikan layout Majalah BMT seperti cover dan ilustrasi/gambar pada setiap berita mampu menjadi daya tarik bagi Majalah BMT. Hal ini sejalan dengan penelitian oleh Pratama (2017) bahwa tampilan suatu rubrik mempengaruhi minat baca suatu komunitas tertentu, walaupun derajat korelasi yang dihasilkan berada pada taraf rendah. Selaras dengan penelitian tersebut Arham (2018) menyatakan bahwa desain visual berpengaruh terhadap daya tarik suatu surat kabar dan selanjutnya meningkatkan minat membaca majalah tersebut.

Kemenarikan judul berita terukur melalui item pertanyaan seperti: (1) Apakah judul dalam setiap berita yang ada di Majalah BMT membuat pembaca tertarik untuk membaca; (2) Apakah setelah membaca judul berita, pembaca melanjutkan dengan membaca isi berita; (3) Apakah judul pada setiap berita di Majalah BMT sudah sesuai dengan isi berita; serta (4) Apakah pembaca dapat memahami maksud/arti pada setiap judul berita yang ada di Majalah BMT.

Sebagian besar sampel penelitian (52\%) judul berita yang ada di Majalah BMT dipersepsikan memiliki kemenarikan sedang. Namun demikian sekitar $36 \%$ sampel penelitian menilai kemenarikan judul berita pada majalah tersebut tinggi. Hal tersebut dapat menjadi catatan bagi pengelola Majalah BMT untuk meningkatkan kualitas penulisan judul berita dalam menarik minat pembaca.

Judul berita menjadi daya tarik awal pembaca untuk membaca sebuah berita. Judul tersebut akan menimbulkan keinginan untuk melanjutkan membaca isi berita atau pun tidak. Oleh karena itu, seringkali penulis berita menggunakan teknik tertentu untuk membuat judul berita menjadi lebih menarik (Meyridah, 2015).

Distribusi frekuensi variabel kemenarikan isi Majalah BMT yang diukur berdasarkan indikator gabungan empat dimensi, yaitu layout majalah, judul berita, penggunaan bahasa, dan kemudahan mengerti isi disajikan dalam Tabel 1.

Tabel 1

Kemenarikan Isi Berita

\begin{tabular}{llcc}
\hline \multicolumn{1}{r}{ Kategori } & Interval & Frekuensi & $\%$ \\
\hline Sangat Tinggi & $>40$ & 2 & 8 \\
Tinggi & $36-40$ & 15 & 60 \\
Sedang & $31-35$ & 3 & 12 \\
Rendah & $26-30$ & 5 & 20 \\
\hline
\end{tabular}

Sumber : Pengolahan Data

Berdasarkan Tabel 1 diketahui bahwa lebih dari separo responden $(60 \%)$ menilai kemenarikan isi berita dalam majalah Bumi Mina Tani berada dalam kategori tinggi. Ini menunjukkan isi berita yang ada dalam Majalah BMT menarik bagi karyawan Setda Pati. Namun demikian, masih ada responden yang menganggap kemenarikan isi berita dalam Majalah BMT dalam kategori rendah. Karena itu, upaya untuk meningkatkan kemenarikan isi berita Majalah BMT masih perlu dilakukan.

\section{Minat Membaca Majalah BMT}

Variabel minat membaca terukur melalui empat dimensi, yaitu perhatian terhadap bacaan, motivasi membaca, Sikap terhadap bacaan, dan kepuasan terhadap Bacaan. Perbandingan terhadap keempat dimensi me- 
nunjukkan bahwa dimensi motivasi membaca dan kepuasan terhadap bacaan memberikan kontribusi tertinggi terhadap minat membaca Majalah BMT.

Motivasi membaca diukur melalui tiga item pertanyaan, yaitu: tiga item pertanyaan yaitu : (1) apakah timbul ketertarikan untuk membaca saat pembaca melihat tampilan Majalah BMT?; (2) Apakah konten/rubrik yang ada di Majalah BMT dapat membuat pembaca merasa ingin membaca; (3) Apakah saat membaca majalah terdapat perasaan terpaksa.

Analisis deskriptif menunjukkan bahwa 64\% sampel penelitian menyatakan selalu dan sering membaca Majalah BMT. Tampilan Majalah BMT seringkali menimbulkan ketertarikan responden untuk membaca. Meskipun tidak semua rubrik yang ada di BMT membuat responden ingin membaca, namun responden mengungkapkan tidak ada paksaan saat membaca tiap berita yang ada di Majalah BMT

Kepuasan terhadap bacaan diukur melalui tiga item pertanyaan yaitu : 1) Apakah pembaca menyukai tampilan Majalah BMT yang pernah terbit?; 2) Apakah pembaca merasa puas dengan aneka ragam rubrik/ konten Majalah BMT yang pernah terbit?; serta 3) Apakah pembaca merasa puas dengan isi berita selama ada terbitan Majalah BMT di Pemkab Pati.

Analisis deskriptif menunjukkan bahwa $44 \%$ sampel penelitian menyatakan sangat puas dan $32 \%$ lainnya menyatakan puas terhadap bacaan yang dimuat pada Majalah BMT. Adapun kepuasan utama pembaca bersumber dari keragaman rubrik dan isi berita yang ditampilkan.

Dua dimensi pada variabel minat membaca, yaitu Perhatian terhadap Bacaan dan Sikap terhadap Bacaan memiliki kontribusi yang lebih rendah dibandingkan dua dimensi sebelumnya. Dimensi Perhatian terhadap Bacaaan diukur melalui tiga item pertanyaan, yaitu: (1) Apakah pembaca memperhatikan konten/rubrik Majalah BMT saat ini?; (2) Apakah pembaca mengikuti setiap edisi Majalah BMT yang diterbitkan?; dan (3) Apakah menurut pembaca di Majalah BMT selalu mengikuti perkembangan terbaru di Kabupaten Pati? Pengukuran terhadap kedua dimensi Perhatian terhadap Bahan Bacaan menunjukkan bahwa sebagian besar responden (40\%) hanya memberikan cukup perhatian terhadap bacaan yang ditampilkan oleh Majalah BMT.

Pengukuran terhadap dimensi sikap terhadap bacaan dilakukan melalui tiga item pertanyaan, yaitu: (1) Apakah pembaca menantikan Majalah BMT edisi terbaru?; (2) Apakah pembaca pernah merasa jenuh saat membaca Majalah BMT?; serta 3) Apakah pembaca pernah menyarankan orang lain untuk ikut membaca Majalah BMT? Analisis deskriptif terhadap dimensi tersebut menunjukkan bahwa sebagian besar responden (56\%) memiliki sikap cukup baik (positif) terhadap konten Majalah BMT.

Berdasarkan hasil pengukuran dimensi Perhatian terhadap Bahan Bacaan dan dimensi Sikap terhadap Bahan Bacaan dapat dinyatakan bahwa kedua dimensi ini lah yang selanjutnya membutuhkan perhatian pengelola Majalah BMT untuk ditingkatkan kinerjanya. Simatupang \& Sulandjari (2017) menyatakan bahwa minat untuk membaca sebuah media diantaranya dipengaruhi oleh kemampuan media tersebut untuk memenuhi kebutuhan pembaca akan suatu informasi. Apabila suatu media mampu menampilkan informasi yang dibutuhkan oleh pembaca secara efektif, maka minat untuk membaca media tersebut juga akan tinggi.

Distribusi frekuensi Variabel Minat Membaca Majalah BMT Karyawan Sekretariat 
Daerah Kabupaten Pati berdasarkan gabungan empat dimensi, yaitu Perhatian terhadap Bacaan, Motivasi Membaca, Sikap terhadap Bacaan, dan Kepuasan terhadap Bacaan disajikan dalam Tabel 2.

Tabel 2.

Minat Membaca Karyawan Setda Kabupaten Pati

\begin{tabular}{llcc}
\hline \multicolumn{1}{c}{ Kategori } & \multicolumn{1}{c}{ Interval } & Frekuensi & $\%$ \\
\hline Sangat Tinggi & $>32$ & 7 & 28 \\
Tinggi & $27-32$ & 10 & 40 \\
Sedang & $21-26$ & 7 & 28 \\
Rendah & $15-20$ & 1 & 4 \\
\hline
\end{tabular}

Sumber :Pengolahan Data, 2014

Berdasarkan Tabel 2 dapat diketahui bahwa sebanyak 40\% karyawan Setda Kabupaten Pati memiliki minat yang tinggi untuk membaca Majalah BMT. Para karyawan Setda Kabupaten Pati menjadikan Majalah BMT sebagai salah satu bacaan mereka.

\section{Hubungan Kemenarikan Isi Berita dengan Minat Membaca}

Tabulasi silang antara kemenarikan isi berita dalam Majalah BMT (X) dengan minat membaca karyawan Sekretariat Daerah Kabupaten Pati (Y) disajikan pada Tabel 3.

Berdasarkan Tabel 3. diketahui bahwa persilangan variabel kemenarikan isi berita Majalah BMT dengan minat membaca karyawan memiliki persentase tertinggi sebesar $40 \%$ pada kategori tinggi. Artinya kategori yang tinggi pada kemenarikan isi berita diikuti dengan minat baca yang tinggi juga. Selanjutnya dilakukan analisis korelasional untuk mengukur kekuatan hubungan kedua variabel tersebut menggunakan analisis korelasi Spearman Rank. Nilai korelasi $\left(\mathrm{r}_{\mathrm{s}}\right)$ yang didapat adalah 0,99 . Adapun nilai kritis untuk jumlah sampel 25 dengan derajat kesalahan 5\% adalah 0,526 (H1> H0). Oleh karena itu dapat dinyatakan bahwa hipotesis dapat diterima atau variabel kemenarikan isi berita memiliki korelasi positif dengan minat membaca Majalah BMT. Secara lebih spesifik dapat dinyatakan bahwa saat variabel kemenarikan isi berita memiliki frekuensi nilai sangat tinggi dan tinggi, maka minat membaca karyawan akan cenderung tinggi pula. Begitu juga sebaliknya, saat frekuensi kemenarikan isi berita berada pada kategori sedang dan rendah, maka responden akan mengatakan bahwa minat mereka untuk membaca juga sedang atau pun rendah.

Hasil penelitian tersebut mendukung hasil penelitan sebelumnya bahwa isi rubrik berita pada sebuah surat kabar dapat mempengaruhi minat membaca dengan cara mempengaruhi fungsi kognisi, afeksi, dan konasi para pembacanya. Perubahan fungsi tersebut selanjutnya dapat berpengaruh terhadap perubahan perilaku pembacanya (Putri, 2018).

Tabel 3

Tabulasi Silang Kemenarikan Isi Berita dalam Majalah BMT dengan Minat Membaca Karyawan Setda Kabupaten Pati

\begin{tabular}{lccccc}
\hline Minat Membaca & \multicolumn{5}{c}{ Kemenarikan Isi Berita (\%) } \\
\cline { 2 - 6 } Karyawan (\%) & Sangat Tinggi & Tinggi & Sedang & Rendah & Jumlah \\
\hline Sangat Tinggi & 8 & 20 & 0 & 0 & 7 \\
Tinggi & 0 & 40 & 0 & 0 & 10 \\
Sedang & 0 & 0 & 12 & 16 & 7 \\
Rendah & 0 & 0 & 0 & 4 & 1 \\
Jumlah & 8 & 60 & 12 & 20 & 25 \\
\hline
\end{tabular}

Sumber : Pengolahan Data, 2014 
Perilaku minat baca pada awalnya dimulai dari proses mempersepsikan stimulus yang diterima oleh indera berupa fisik, visual, maupun komunikasi verbal. Selanjutnya ketika stimulus tersebut dipersepsikan secara positif diteruskan kepada proses pemahaman dan pengetahuan. Apabila stimulus yang diterima dapat memenuhi kebutuhan pembaca secara kontinyu, berlanjut kepada proses afeksi yang termanifestasi dalam kesukaan terhadap media tersebut serta proses konasi yang melibatkan minat dan sikap yang positif untuk membaca media tersebut (Kusuma, 2012). Selanjutnya, minat membaca Majalah BMT yang tinggi diharapkan dapat meningkatkan pengetahuan para karyawan Setda mengenai perkembangan kebijakan serta program/kegiatan yang sedang dilaksanakan oleh pemerintah daerah.

\section{KESIMPULAN DAN SARAN}

\section{Kesimpulan}

Dimensi kesesuaian bahasa dan kemudahan mengerti isi berita memberikan kontribusi tertinggi terhadap variabel kemenarikan isi berita. Adapun pada variabel minat membaca, dimensi yang memiliki kontribusi tertinggi adalah motivasi membaca dan kepuasan terhadap bacaan. Uji korelasi Spearman rank menunjukkan adanya hubungan positif dan signifikan antara kemenarikan isi berita dengan minat membaca Majalah BMT pada karyawan Setda Kabupaten Pati.

\section{Saran}

Redaksi Majalah BMT perlu mengadakan evaluasi terhadap terbitan majalah yang ditujukan untuk sarana menyebarluaskan informasi Pemkab Pati.

Berkaitan dengan Kemenarikan Isi Berita, sebaiknya dilakukan perbaikan terhadap pemilihan judul serta layout majalah. Selain itu, untuk meningkat minat membaca upaya yang perlu dilakukan adalah meningkatkan perhatian terhadap bacaan dan sikap terhadap bacaan dengan meningkatkan kualitas terbitan dan perbaikan manajemen pengelolaan Majalah BMT.

\section{DAFTAR PUSTAKA}

Ardianto, E., Komala, L. (2004). Komunikasi Massa: Suatu Pengantar. Bandung: Remaja Rosdakarya.

Arham, Koagouw, F. V . I. A., Onsu, R. (2018). Desain Komunikasi Visual Surat Kabar Manado Post terhadap Keputusan Membaca Mahasiswa Ilmu Komunikasi Sosial dan Politik Universitas Sam Ratulangi. Acta Diurna, 7(2), 1-11

Assegaf, H. D. (1982). Hubungan Masyarakat dalam Praktek. Jakarta: Ghalia Indonesia.

Astrid, A. F. (2017). Eksistensi Media Internal Sebagai Alat Kehumasan (Studi Kasus Majalah Empati PSMP Toddopuli Makasar). Jurnalisa, 03(1), 136-140.

Hadi, S. (1986). Metodologi Research I. Yogyakarta: Yayasan Penerbit Fakultas Psikologi UGM.

Kusuma, T. A. (2012). Pengaruh Majalah Pemeriksa terhadap Pengetahuan Auditor. Wacana, IX(3), 224-247

Meinanda, T. (1981). Pengantar Ilmu Komunikasi dan Jurnalistik, Bandung: Armico.

Meichati, S. (1972). Motivasi Membaca. Semarang : Effhar Offset.

Meyridah. (2015). Pemakaian Metafora dalam Judul Berita di Media Massa Cetak Kalimantan Selatan. Jurnal Bahasa, Sastra dan Pembelajarannya, 5(1), 94-99

Poentarie, E. (2015). Bahasa Sensasional dalam Pemberitaan Media. Widyaparwa, 43(2), 103-114 
Poerwodarminto, W. J. S. (1985). Kamus Bahasa Indonesia. Jakarta: PN. Balai Pustaka

Pratama, M. A. N. (2017). Pengaruh Layout Rubrik Bike tp Work Online Greeners.co terhadap Minat Baca Komunitas Bersepeda (Studi Korelasional pada Komunitas Bersepada Federal Bandung, Indonesia). Tugas Akhir. Fakultas Dakwah dan Komunikasi Program Studi Jurnalistik. UIN Sunan Gunung Djati (tidak diterbitkan).

Putri, Z. S. (2018). Pengaruh Rubrik Persib Mania pada Surat Kabar Tribun Jabar terhadap Minat Baca Santri Al-Falah Dago. Tugas Akhir (tidak dipublikasikan). Fakultas Dakwah dan Komunikasi. Program Studi Jurnalistik. UIN Sunan Gunung Djati.

Rahim, F. (2005). Pengajaran Membaca di Sekolah Dasar. Jakarta: Bumi Aksara.
Simatupang, H. D., Sulandjari, R. (2017). Efektifitas Media Internal Majalah Gema Serasi Sebagai Sarana Pemenuhan Kebutuhan Informasi Pegawai Pemerintahan Daerah di Kantor Bupati Semarang. Jurnal Egaliter, 1(1).

Singarimbun, M. (1989). Metode Penelitian Survai, Edisi Revisi. Jakarta: LP3ES.

Sumadiria, A. S. H. (2005). Jurnalistik Indonesia: Menulis Berita dan Feature. Bandung: Simbiosa Rekatama Media.

(2006). Bahasa Jurnalistik: Panduan Praktis Penulis dan Jurnalis. Bandung: Remaja Rosdakarya.

\section{BIODATA PENULIS}

Putri Oktiningtyas, lahir 3 Oktober 1988 di Semarang. Sarjana Komunikasi dari Sekolah Tinggi Ilmu Komunikasi Semarang. Saat ini bekerja sebagai Pranata Humas di Sekretariat Daerah Kabupaten Pati. 